\title{
DISTRIBUTION OF CERTAIN AUTOANTIBODIES IN MONOZYGOTIC AND DIZYGOTIC TWINS
}

\author{
W. WATSON BUCHANAN, J. A. BOYLE, W. R. GREIG, R. MCANDREW,* \\ M. BARR, J. R. ANDERSON,** AND R. B. GOUDIE \\ From The Centre for Rheumatic Diseases, Baird Street, the University Department of Medicine, \\ Royal Infirmary, and the University Department of Pathology, Western Infirmary, Glasgow
}

It is now well established that autoantibodies are found in a number of disease conditions such as Hashimoto's disease and primary hypothyroidism (Roitt and Doniach, 1958, 1960; Buchanan and Harden, 1965), pernicious anaemia (Doniach, Roitt, and Taylor, 1963; Irvine, 1965), and some connective tissue diseases, notably rheumatoid arthritis (Vaughan, 1959; Singer, 1961; Christian, 1963) and systemic lupus erythematosus (Holman, 1960; Shulman, 1963), but the significance of the autoantibodies in these diseases is unknown. Several groups of workers have reported familial aggregation of serum autoantibodies in Hashimoto's disease (Hall, Owen, and Smart, 1960; Hall, DeGroot, McDermott, and Davis, 1962), pernicious anaemia (Doniach, Roitt, and Taylor, 1965), rheumatoid arthritis (Lawrence and Ball, 1958; Ziff, Schmidt, Lewis, and Tanner, 1958; Bremner, Alexander, and Duthie, 1959; Robecchi and Daneo, 1959; Lawrence, Laine, and de Graaff, 1961), and systemic lupus erythematosus (Brunjes, Zike, and Julian, 1961 ; Siegal, Lee, Widelock, Reilly, Wise, Zingale, and Fuerst, 1962; Leonhardt, 1964). However, it is not known whether this familial aggregation is genetically or environmentally determined. Furthermore, Bunim and his colleagues (Bunim, Burch, and O'Brien, 1964; Burch, O'Brien, and Bunim, 1964), in a careful epidemiological study of the North American Indians, failed to find familial aggregation of rheumatoid factor.

Autoantibodies found in the diseases mentioned above exist in low titre in some normal individuals (Goudie, Anderson, and Gray, 1959; Alexander, Bremner, and Duthie, 1960; Hackett, Beech, and

\footnotetext{
*Present address: Head of Department, Blood Transfusion Service, Royal Infirmary, Glasgow.

* Present address: Professor of Pathology, University Department of Pathology, Liverpool, England.
}

Forbes, 1960; Ball and Lawrence, 1961 ; Hill, 1961; Buchanan, Harden, Koutras, and Gray, 1965). We therefore thought it of interest to contrast the concordance rates of autoantibodies in monozygotic and dizygotic healthy twins in an attempt to evaluate the relative role of genetic and environmental factors in autoantibody production. The autoantibodies studied include autoantibodies to thyroid "microsomes" and thyroglobulin, autoantibodies to the cytoplasm of the gastric parietal cell, rheumatoid factor, and antinuclear autoantibody (antinuclear factor).

\section{Twin Sample}

\section{Material and Methods}

A sample of 145 healthy twin pairs was obtained by advertisement in the local newspapers and on radio, by advertisement in out-patient departments in hospitals in Glasgow, and by writing to the parents of twin schoolchildren in Glasgow. The names of the twin schoolchildren were obtained from the headmasters of the schools.

The twins who replied to the advertisements and the twins from the schools who accepted the invitation to participate in the study were seen irrespective of the presence of known disease. Osborne and de George (1959) have commented that, while it is probably impossible to avoid bias in the selection of a twin sample, it is desirable to know the direction of the bias. Since the ascertainment campaign mentioned rheumatoid arthritis, the sample probably contains a disproportionate representation from family groups with sufferers from this disease. Any familial aggregation will thus probably be reflected in the twins in higher autoantibody levels and in a higher prevalence of rheumatoid arthritis than in a completely random sample. In fact, one member of each of two dizygotic pairs in the sample had rheumatoid arthritis and one member of another dizygotic pair had chronic glomerulonephritis. These have not been excluded from the analysis. 
It is not apparent that other departures from random sampling, such as an excess of females or of monozygotic pairs (Table I) or the fact that the twins were of a co-operative disposition and probably of above average intelligence, are relevant to this study.

\section{Determination of Zygosity}

The criteria used in determining zygosity were those of Newman, Freeman, and Holzinger (1937). The like-sex pairs were examined with respect to their general appearance and likeness, colour and texture of hair, eye colour, skin colour, facial likeness, types of teeth, hands, fingers, and types of nails. The presence of reversed asymmetry in handedness and hair whorls was also taken as confirmatory evidence of monozygosity. Fingerprints and palm prints were examined for zygosity using the criteria of Holt (1961), and in some pairs examination of dental casts of the teeth and cephalogram $x$ rays of the head were performed. The following blood group antigens were examined $\mathrm{A}_{1}, \mathrm{~A}_{2}, \mathrm{~B}, \mathrm{O}$; M, N, S, s; C, D, E, c, d, e; Kell; Duffy (a) and $P$.

The sex and age distribution of the different categories of twins are shown in Table I. The majority of the twins were young and with the exception of a slightly disproportionate number of monozygotic female pairs in the 20 to 30 decade, the age distribution was similar in all groups.

\section{Methods}

The tanned red-cell haemagglutination test for antithyroglobulin was performed using thyroglobulin-coated formolized tanned sheep red cells (Burroughs Wellcome) (Fulthorpe, Roitt, Doniach, and Couchman, 1961). The lowest serum dilution tested was 1 in 4.

Autoantibody to thyroid "microsomes" was measured by an indirect immunofluorescence technique on unfixed frozen sections of thyroid slices (Holborow, Brown, Roitt, and Doniach, 1959) using test serum diluted 1 in 4 in the first layer.

Autoantibodies to the cytoplasm of human gastric parietal cell were detected by an indirect immunofluorescence technique (Adams, Glen, Kennedy, MacKenzie,
Morrow, Anderson, Gray, and Middleton, 1964), serum being tested at a dilution of 1 in 4 .

Rheumatoid factor was determined by the Hyland latex (RA) test technique (Hyland Laboratories, Cah: fornia). All sera were screened at a dilution of 1 in $\overrightarrow{20}$ and the presence of agglutination was recorded 15 and seconds after mixing the reagents. Agglutination either 15 or 45 seconds was recorded as positive.

Antinuclear autoantibody was detected by the indiree immunofluorescence technique described by Beck (196B on cryostat sections of rat liver. The lowest serum diluz tion tested was 1 in 4 . The morphological patterns of nuclear staining (homogenous, speckled, and nucleola $\$$ produced by antinuclear autoantibodies were defined by the criteria of Beck $(1961,1962,1963)$.

For the immunofiuorescence tests for thyroid and gas tric antibodies commercially prepared anti-IgG conjuga (Burroughs Wellcome) was used. For the antinuclear teso anti-IgG prepared and conjugated in this laboratory was used. Specimens of serum were tested in random groups each group including sera from monozygotic and dizygot twins, without knowledge of their identity. The sensi tivity of the antibody tests was maintained by inclusion of known weak and strong positive sera in each batch of tests.

\section{Results}

The results are summarized in Table I. Whe $\overrightarrow{9}$ considering total concordance, it is necessary include not only twins both of whom have detectie autoantibody (positive concordance) but also thros exhibiting negative concordance (neither twin havin detectable autoantibody). The results which ary presented in this study have been obtained by analys of the data on this definition of concordance. The data have, however, also been examined using onl twins who exhibited positive concordance and similar results have been obtained.

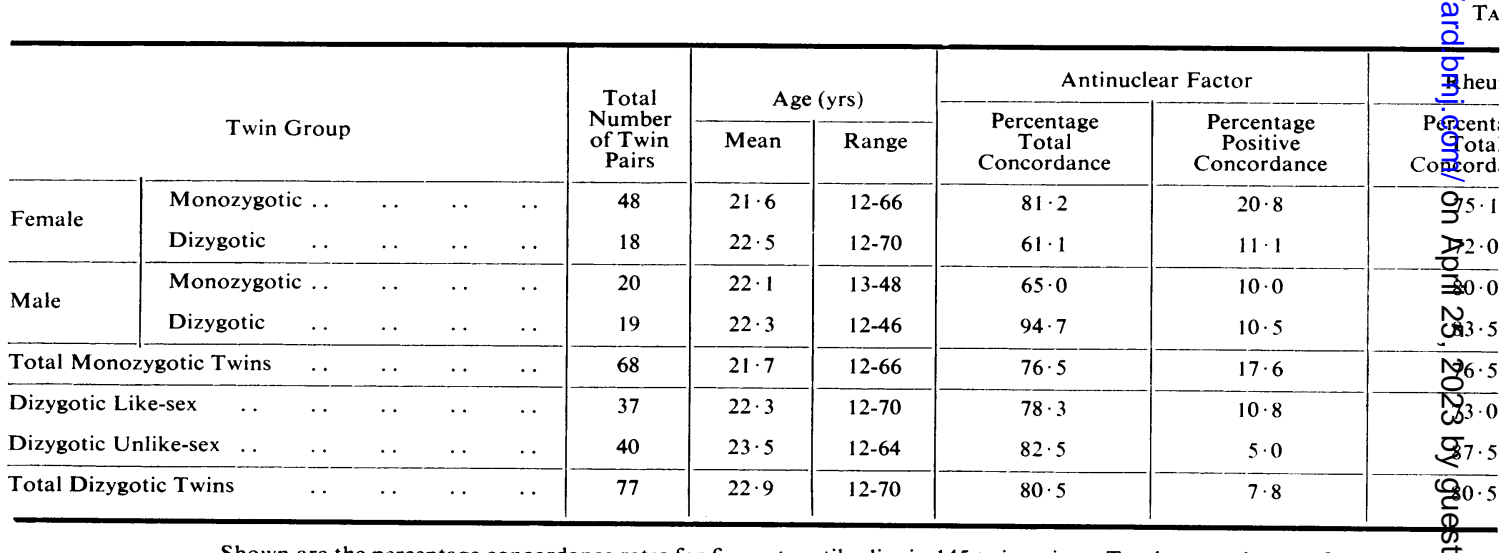


TABLE II

ESTIMATES OF HERITABILITY COEFFICIENT $h^{*}$

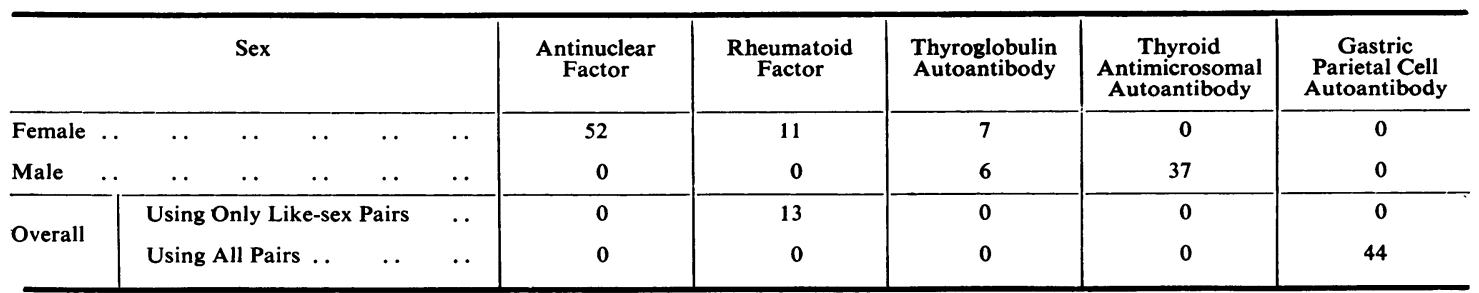

*Holzinger's heritability coefficient $h$ for five autoantibodies. The calculation of this statistic is explained in the text.

In those tests where serial dilutions were made, namely the tanned red-cell haemagglutination test for thyroglobulin autoantibodies and the immunofluorescent test for antinuclear factor, the difference in autoantibody titre within positively concordant pairs was more than one tube dilution in only three instances. Two of these were female monozygotic twins and one pair were like-sex female dizygotic twins.

There is in general a low yield of positive autoantibody tests, and in particular positive tests for gastric parietal cell autoantibody are uncommon. The overall results, however, are very similar when the monozygotic and dizygotic male and female twin pairs are compared. In order to determine the relative roles of heredity and environment in autoantibody production, we have calculated Holzinger's heritability index, $h$, a crude measure of the relative importance of the two components which is derived from the formula (Newman and others, 1937):

\footnotetext{
per cent. monozygotic - per cent. dizygotic

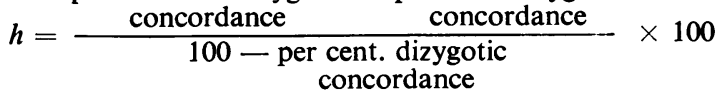

The values of $h$ for the autoantibodies in this study are shown in the third line of Table II, where it can be seen that for all autoantibodies studies the $h$ values were low, the highest being 52 per cent. in the case of antinuclear factor. This finding suggests that in all cases the influence of heredity is slight and that the development of the autoantibodies under study is largely environmentally determined.

\section{Organ Specific Autoantibodies}

Table I shows that the incidence of positive tests for thyroglobulin and thyroid "microsomal" autoantibodies was low. Nevertheless there was no trend to increased rates of concordance among male or female monozygotic twins when compared either to male and female like-sex dizygotic twins or to unlike-sex dizygotic twins.

The incidence of positive tests for autoantibodies to gastric parietal cell in this young population was so low as to render interpretation impossible.

\section{Non-organ Specific Autoantibodies}

There was a much higher yield of positive results for those autoantibodies that are not organ specific.

;ULTS OF AUTOANTIBODY TESTS IN 145 TWIN PAIRS

\begin{tabular}{|c|c|c|c|c|c|c|}
\hline \multirow{2}{*}{$\begin{array}{l}\text { 'ercentage } \\
\text { Positive } \\
\text { incordance }\end{array}$} & \multicolumn{2}{|c|}{ Thyroglobulin Autoantibody } & \multicolumn{2}{|c|}{ Thyroid "Antimicrosomal" Autoantibody } & \multicolumn{2}{|c|}{ Gastric Parietal Cell Autoantibody } \\
\hline & $\begin{array}{c}\text { Percentage } \\
\text { Total } \\
\text { Concordance }\end{array}$ & $\begin{array}{l}\text { Percentage } \\
\text { Positive } \\
\text { Concordance }\end{array}$ & $\begin{array}{c}\text { Percentage } \\
\text { Total } \\
\text { Concordance }\end{array}$ & $\begin{array}{c}\text { Percentage } \\
\text { Positive } \\
\text { Concordance }\end{array}$ & $\begin{array}{c}\text { Percentage } \\
\text { Total } \\
\text { Concordance }\end{array}$ & $\begin{array}{c}\text { Percentage } \\
\text { Positive } \\
\text { Concordance }\end{array}$ \\
\hline $6 \cdot 3$ & $89 \cdot 6$ & $2 \cdot 1$ & $77 \cdot 1$ & $10 \cdot 4$ & $97 \cdot 9$ & 0 \\
\hline $5 \cdot 6$ & $88 \cdot 8$ & 0 & $94 \cdot 4$ & $5 \cdot 6$ & $94 \cdot 4$ & 0 \\
\hline $5 \cdot 0$ & $95 \cdot 0$ & 0 & $90 \cdot 0$ & $\mathbf{0}$ & $90 \cdot 0$ & 0 \\
\hline$+5 \cdot 3$ & $94 \cdot 7$ & $\mathbf{0}$ & $84 \cdot 1$ & 0 & 100 & 0 \\
\hline $5 \cdot 9$ & $91 \cdot 2$ & $1 \cdot 5$ & $81 \cdot 9$ & $7 \cdot 4$ & $95 \cdot 6$ & 0 \\
\hline $5 \cdot 4$ & $91 \cdot 9$ & 0 & $89 \cdot 2$ & $2 \cdot 7$ & $97 \cdot 3$ & 0 \\
\hline $5 \cdot 0$ & $92 \cdot 5$ & $2 \cdot 5$ & $82 \cdot 5$ & $5 \cdot 0$ & $87 \cdot 5$ & 0 \\
\hline $5 \cdot 2$ & $92 \cdot 2$ & $1 \cdot 3$ & $85 \cdot 7$ & $3 \cdot 9$ & $92 \cdot 2$ & 0 \\
\hline
\end{tabular}

detectable or no detectable autoantibody. Positive concordance refers to twins both having detectable autoantibody. 
Table I shows that the concordance rate for antinuclear factor was $81 \cdot 2$ per cent. for monozygotic female and $61 \cdot 1$ per cent. for dizygotic female twins. When one considers the males, it will be seen that the monozygotic concordance was actually lower than the dizygotic concordance $(65 \cdot 0$ and $94 \cdot 7$ per cent. respectively). Calculation of $h$ (Table II), however, using all like-sex pairs was zero, and when unlike-sex pairs were used $h$ remained zero.

The concordance rates for rheumatoid factor in both male and female mono- and dizygotic twins was very similar, being $75 \cdot 1$ and $72 \cdot 0$ per cent. respectively for the females and 80.0 and 83.5 per cent. for the males (Table I). The $h$ estimate in the females was 11 per cent. and in the males it was less than zero. Overall calculation of $h$ using like-sex pairs was 13 per cent. and when unlike-sex pairs were used it was zero.

In this study there were sixty pairs of twins over the age of 30 years. Examination of the results of the various autoantibody tests showed the expected increase in prevalence and in titre of autoantibodies with increasing age. However, the ratios of concordance to discordance rates in this group were similar to those observed in twin pairs less than 30 years of age.

\section{Discussion}

The results of this work show that there is no increase in the concordance exhibited by monozygotic male and female twins compared to dizygotic twins for four of the five autoantibodies studied: autoantibodies to thyroid "microsomes" and to thyroglobulin, rheumatoid factor, and antinuclear factor. The number of twins positive for the fifth autoantibody (to cytoplasm of the gastric parietal cell) was too low to allow any interpretation. The failure to demonstrate increased autoantibody concordance in mono- as compared to dizygotic twins in this predominantly young population also obtained when the results for those twins greater than 30 years of age were abstracted and analysed as a separate group. Although the prevalence and titre of the autoantibodies were higher in this older group, the ratio of concordance in monozygotic compared to dizygotic twins was the same as in the younger twins. It therefore seems unlikely on the basis of the data from this study that the results would have been substantially different had an older group of twins been tested. However, only sixty twin pairs over the age of $\mathbf{3 0}$ were available for examination and it is not possible to be dogmatic about this point. The calculation of the heritability co-efficient, $h$, gives only a crude assessment of the relative role of heredity and environment in autoantibody production Nonetheless, when one examines this statistic for the autoantibodies under consideration, it is seen that the highest individual estimate is 13 per cent. (Table: II), if, to avoid sex effects, only like-sex pairs are con sidered. If all pairs are considered, all estimates of are below zero, except that for the gastric autoantic body ( $h=44$ per cent.), but this latter estimate i subject to enormous statistical fluctuation owing to the rarity of detectable antibody. Similar unrelia bility applies to the $h$ estimates from both thyroid autoantibodies, and the main value of the findings $i \vec{\nabla}$ these three classes of autoantibody is to show that there is no serious heterogeneity between differeny antibodies.

The difference between the sexes in the estimate of $\frac{\vec{R}}{R}$ based on the rheumatoid factor is not statistically significant and that for antinuclear factor is of border line significance

$$
\text { (uncorrected } \frac{2}{3}=8 \cdot 0 ; 0.02<P>0.05 \text {, }
$$

but this $x^{2}$ is probably somewhat overestimate $\oint^{\circ}$ because of the small numbers). It is difficult to fin a satisfactory biological explanation for a sex differs ence in the true heritability and at present we prefer $t$ interpret the discrepancy as due to chance fluctuations. These data therefore suggest that in the productionfof autoantibodies in young healthy persons enviran? mental influences are predominant.

Whether it is possible to extrapolate these co clusions made on mainly healthy individuals to th autoimmune diseases associated with the autoant bodies studied is not certain for a number of reasons First, it is not known whether the existence of low titre autoantibodies in health is due to the same ung known cause responsible for the appearance of higho titre autoantibodies in disease states. Secondly, it is not certain that the low-titre autoantibodies found in apparently healthy individuals are merely quantie tatively different from those circulating in high titre in the autoimmune diseases. Buchanan and his associates (Buchanan and others, 1965), studying euthyroid agoitrous females with complement-fixing autoantibodies to thyroid "microsomes" in low dilution, have demonstrated minor but consistents abnormalities of stable iodine metabolism similar 0 . the more marked changes which they found in Hashimoto's disease (Buchanan and others, 1961). Goudie and others (1959) found a correlation betweet the presence of circulating "anti-microsomal thyroid autoantibodies and focal thyroiditis in necropsy study of patients dying without clinicad evidence of thyroid disease. These two observations suggest that the presence of thyroid autoantibodies in 
low titre may reflect minor degrees of thyroid autoimmune disease and that these autoantibodies are probably qualitatively similar to those found in high titre in Hashimoto's disease. When one considers rheumatoid and antinuclear factor, the position is unfortunately not known. Several differences, however, have been noted between the agglutinators of the $\mathrm{Gm}$ and InV determinants in rheumatoid sera (Ragg agglutinators) and those found in normal sera (Snagg agglutinators) (Steinberg, 1962; Fudenberg and Martensson, 1963).

The results of this study suggest that it would be desirable, though subject to certain difficulties arising from case selection, to undertake further studies into the clinical and immunological status of monozygotic and dizygotic twins, one or both of whom show clinical manifestations of the diseases known to be associated with the presence of circulating autoantibodies.

\section{Summary}

Five autoantibodies were studied in 145 pairs of predominantly healthy young twins: thyroid "microsomal" antibody, gastric parietal cell antibody, and antinuclear factor by indirect immunofluorescence techniques, antithyroglobulin by tanned red cell agglutination, and rheumatoid factor by the Hyland latex (RA) test. Analysis of the concordance rates in monozygotic and dizygotic twin pairs suggests that in healthy people the predisposition to form these autoantibodies is largely governed by environmental factors rather than genetic influences.

It is a pleasure to acknowledge the willing co-operation of the twins from the city of Glasgow who took part in this study. Our thanks are also due to Dr.T.Scott Wilson, Medical Officer of Health for the Glasgow Corporation Education Department, Mr. I. Thorburn of the Evening Citizen, the British Broadcasting Corporation for help in the ascertainment of the twins, and to Chief Superintendent D. Hamilton, Identification Bureau, City of Glasgow Police, for analysis of fingerprint patterns. The invaluable assistance of Miss Hogg and Miss McCleish of the Women's Voluntary Service is gratefully acknowledged.

We wish in particular to thank Dr. J. H. Renwick, Reader in Human Genetics, Department of Genetics, University of Glasgow, for invaluable assistance in the interpretation and analysis of the data from this study and for reading the manuscript.

This work was supported in part by a grant from the Arthritis and Rheumatism Council for Research in Great Britain.

\section{REFERENCES}

Adams, J. F., Glen, A. I. M., Kennedy, E. H., Mackenzie, I. L., Morrow, J. M., Anderson, J. R., Gray, K. G., and Middleton, D. G. (1964). Lancet, 1, 401.
Alexander, W. R. M., Bremner, J. M., and Duthie, J. J. R. (1960). Ann. rheum. Dis., 19, 338.

Ball, J., and Lawrence, J. S. (1961). Ibid., 20, 235.

Beck, J. S. (1961). Lancet, 1, 1203.

(1962). Ibid., 1, 241.

(1963). Scot. med. J., 8, 373.

Bremner, J., Alexander, W. R. M., and Duthie, J. J. R. (1959). Ann. rheum. Dis., 18, 279.

Brunjes, S., Zike, K., and Julian, R. (1961). Amer. J. Med., 30, 529.

Buchanan, W. W., and Harden, R. McG. (1965). Arch. intern. Med., 115, 411.

,-- Koutras, D. A., and Gray, K. G. (1965). J. clin. Endocr., 25, 301.

-, Koutras, D. A., Alexander, W. D., Crooks, J., Richmond, M. H., Macdonald, E. M., and Wayne, E. J. (1961). Ibid., 21, 806.

Bunim, J. J., Burch, T. A., O'Brien, W. M. (1964). Bull. rheum. Dis., 15, 349.

Burch, T. A., O'Brien, W. M., and Bunim, J. J. (1964). Amer. J. publ. Hlth, 54, 1184.

Christian, C. L. (1963). J. chron. Dis., 16, 875.

DeGroot, L. J., Hall, R., McDermott, W. V., and Davis, A. M. (1962). New Engl. J. Med., 267, 267.

Doniach, D., Roitt, I. M., and Taylor, K. B. (1963). Brit. med. J., 1, 1374.

,,--- (1965). Ann. N.Y. Acad. Sci., 124, Part II, p. 605.

Fudenberg, H., and Martensson, L. (1963). Bull. rheumg Dis., 13, 313.

Fulthorpe, A. J., Roitt, I. M., Doniach, D., and Couch man, K. (1961). J. clin. Path., 14, 654.

Goudie, R. B., Anderson, J. R., and Gray, K. G. (1959). J. Path. Bact., 77, 389.

Hackett, E., Beech, M., and Forbes, I. J. (1960). Lancet, $2,402$.

Hall, R., Owen, S. G., and Smart, G. A. (1960). Ibid., 2, 187.

Hill, O. W. (1961). Brit. med.J., 1, 1793.

Holborow, E. J., Brown, P. C., Roitt, I. M., and Doniach, D. (1959). Brit. J. exp. Path., 40, 583.

Holman, H. R. (1960). Ann. Rev. Med., 11, 231.

Holt, S. B. (1961). Brit. med. Bull., 17, 247.

Irvine, W. J. (1965). New Engl. J. Med., 273, 432.

Lawrence, J. S., and Ball, J. (1958). Ann. rheum. Dis., 17, 160.

, Laine, V. A. I., and de Graaff, R. (1961). Proc. roy. Soc. Med., 54, 454.

Leonhardt, T. (1964). Acta med. scand., 176, Suppl. 416, p. 76.

Newman, H. H., Freeman, F. N., and Holzinger, K. J. (1937). "Twins: A Study of Heredity and En- N vironment." Chicago University Press, Chicago. or

Osborne, R. H., and De George, F. V. (1959). "Genetic N Basis of Morphological Variation", p. 25. Har- N vard University Press, Cambridge, Mass.

Robecchi, A., and Daneo, V. (1959). Acta rheum. scand., $5,245$.

Roitt, I. M., and Doniach, D. (1958). Lancet, 2, 1027. 
Roitt, I. M., and Doniach, D. (1960). Brit. med. Bull., $16,152$.

Shulman, L. E. (1963). J. chron. Dis., 16, 889.

Siegel, M., Lee, S. L., Widelock, D., Reilly, E. B., Wise, G. J., Zingale, S. B., and Fuerst, H. T. (1962). Ibid., 15, 131.

Singer, J. M. (1961). Amer. J. Med., 31, 766.

Steinberg, A. G. (1962). In "Progress in Medical Genetics”, vol. 2, ed. A. G. Steinberg, and A. G. Bearn, p. 1. Grune and Stratton, New York.

Vaughan, J. H. (1959). Amer. J. Med., 26, 596.

Ziff, M., Schmid, F. R., Lewis, A. J., and Tanner, M. (1958). Arthr. and Rheum., 1, 392.

La distribution de certains auto-anticorps chez des jumeaux monozygotes et dizygotes

\section{RÉSUMÉ}

On étudia cinq auto-anticorps chez 145 paires de jumeaux, jeunes et essentiellement sains: l'anticorps "microsomique" anti-thyroïde, l'anticorps contre la cellule pariétale gastrique, le facteur anti-nucléaire par la méthode d'immunofluorescence indirecte, l'anti- thyroglobuline par l'agglutination des érythrocyteş tannés et le facteur rhumatoïde par le test au latex de্ Hyland. L'analyse des taux de concordance chez leș paires de jumeaux monozygotes et dizygotes suggère que chez les sujets sains la tendance à la production de ces auto-anticorps est gouvernée en grande partie par des. facteurs ambiants plutôt que génétiques.

La distribución de ciertos auto-anticuerpos en gemelos mon⿳亠丷厂犬 y dicigóticos

SUMARIO

Se estudiaron cinco auto-anticuerpos en 145 parejas dळ๊ gemelos jóvenes y predominantemente sanos: el anticuerpo "microsómico" tiroideo, el anticuerpo contra la célula parietal gástrica, el factor antinuclear por el método de inmunofluorescencia indirecta, la anti

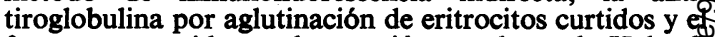
factor reumatoide por la reacción con latex de Hyland El análisis de las cifras de concordancia en parejas dê gemelos mono y dicigóticos sugiere que en sujetos sanộr la tendencia a la formación de estos auto-anticuerpos ser ve gobernada en gran parte por factores ambientes máş bien que genéticos. 